\title{
Moral Support: How Moral Values Shape Foreign Policy Attitudes
}

\section{Citation}

Kertzer, Joshua D., Kathleen E. Powers, Brian C. Rathbun, and Ravi lyer. 2014. “Moral Support: How Moral Values Shape Foreign Policy Attitudes." The Journal of Politics 76 (3) (July): 825-840. doi:10.1017/s0022381614000073.

\section{Published Version}

doi:10.1017/s0022381614000073

\section{Permanent link}

http://nrs.harvard.edu/urn-3:HUL.InstRepos:25757893

\section{Terms of Use}

This article was downloaded from Harvard University's DASH repository, and is made available under the terms and conditions applicable to Other Posted Material, as set forth at http:// nrs.harvard.edu/urn-3:HUL.InstRepos:dash.current.terms-of-use\#LAA

\section{Share Your Story}

The Harvard community has made this article openly available.

Please share how this access benefits you. Submit a story.

Accessibility 


\title{
Moral Support: How Moral Values Shape Foreign Policy Attitudes
}

\author{
Joshua D. Kertzer Harvard University \\ Kathleen E. Powers Ohio State University \\ Brian C. Rathbun University of Southern California \\ Ravi Iyer University of Southern California
}

\begin{abstract}
Although classical international relations theorists largely agreed that public opinion about foreign policy is shaped by moral sentiments, public opinion scholars have yet to explore the content of these moral values, and American IR theorists have tended to exclusively associate morality with liberal idealism. Integrating the study of American foreign policy attitudes with Moral Foundations Theory from social psychology, we present original survey data showing that the five established moral values in psychology—harm/care, fairness/reciprocity, authority/respect, ingroup/loyalty, and purity/sanctity-are strongly and systematically associated with foreign policy attitudes. The "individualizing" foundations of harm/care and fairness/reciprocity are particularly important drivers of cooperative internationalism and the "binding" foundations of authority/respect, ingroup/loyalty, and purity/ sanctity of militant internationalism. Hawks and hardliners have morals too, just a different set of moral values than the Enlightenment ones emphasized by liberal idealists.
\end{abstract}

W hat role do moral values play in shaping foreign policy preferences? ${ }^{1}$ Although morality has been at the center of a number of vigorous debates in International Relations theory-from descriptive disputes about the role that moral norms play in international politics (Tannenwald 1999) to prescriptive arguments about the role moral considerations should play in the study and practice of IR (Carr 1939; Price 2008) classical IR theorists held as self-evident the assumption that American public opinion has moralistic tendencies. For liberal idealists and constructivists, the moral foundation of public opinion, mobilized by norm entrepreneurs, opens up the possibility of positive moral action, whereas for realists, the public's moralism-especially in the United States - is one of the main reasons why foreign policymaking should be insulated from the pressures of public opinion (Morgenthau 1985). A few have questioned the existence of this "moral majority" in foreign policy issues (Drezner 2008; Kertzer and McGraw 2012), but it is largely accepted that American public opinion has moral underpinnings, whether for good (Wilson 1998) or for ill (Morgenthau 1951).

We argue that this conventional wisdom suffers from two important flaws. First, although many prominent IR theorists assumed that American public opinion has moralistic tendencies, public opinion scholars have yet to scrutinize their claims, predominantly focusing on cognitive arguments about costs and benefits rather than affective arguments about moral sentiments (Gelpi, Feaver, and Reifler 2009); if public opinion about foreign policy indeed has moral foundations, we have yet to systematically investigate what these moral foundations are. Second, consistent with the liberal and cosmopolitan lenses through which American IR theorists tend to study norms (Checkel 1998), morality in international politics has largely been understood in the context of liberal and Enlightenment values-eschewing the possibility that militaritstic policies are morally grounded. The social psychology literature, however, emphasizes how liberals and conservatives alike rely on moral

\footnotetext{
${ }^{1}$ An online appendix is available at http://dx.doi.org/10.1017/S0022381614000073. Replication data will be made available at www.kepowers.com by the time of publication.
} 
values, albeit different sets of them (Graham, Haidt, and Nosek 2009; Haidt and Graham 2007). It is also in stark contrast with how moral values are understood in the "values voters" literature in American politics, in which moral values are associated with conservative rather than liberal ideals (Hillygus and Shields 2005).

In this article, we employ original survey data to offer what we believe to be one of the first studies to systematically investigate the moral underpinnings of American foreign policy attitudes. Integrating the study of foreign policy attitudes with the reigning theoretical framework in moral psychology, we find that the classic foreign policy orientations studied by political scientists rely on distinct profiles of moral foundations: hawks and hardliners have morals too, just a different set than those emphasized by liberal idealists; hard-headed considerations of the national interest therefore not only have cultural bases (Johnston 1995) but moral ones as well. We find that while the idealistic foreign policies of humanitarianism and multilateralism ("cooperative internationalism”) are grounded in an Enlightenment morality that values the individual, foreign policies that involve the use of force ("militant internationalism") are equally morally motivated, but by values that emphasize the protection of the community. These effects are substantively strong, explaining around $50 \%$ of the variance in these foreign policy orientations. Isolationism, however, is largely disconnected from the five moral foundations specified by Haidt but may be driven by a commitment to individual liberty. We also show that these distinct moral profiles hold for specific foreign policy issues. Rather than viewing values and interests as opposites, we show that moral values often construct perceptions of what the national interest is, thereby offering one explanation for why there is so much disagreement about the shape that American foreign policy should take in the world. Our argument proceeds in six parts. We first review the classic debate about morality in international relations theory before introducing Moral Foundations Theory from social psychology, whose enumeration of five distinct moral values, we believe, offers an attractive framework for thinking about the origins of foreign policy attitudes. After linking these sets of moral foundations to the three classic foreign policy orientations-cooperative internationalism (CI), militant internationalism (MI), and isolationism-we discuss our unique survey, present our results, and conclude by discussing the implications of our findings.

\section{Morality in International Relations Theory: Liberal Values, Reason, and the Mass Public}

Morality is at the heart of systematic thinking about international relations. The "first great debate" between realists and liberal idealists, which helped define the core theoretical cleavages in international relations theorizing, was largely over the role that morality played in foreign affairs (Nicholson 1998). While a number of scholars have pointed out that this debate was somewhat illusory, since actual idealists are hard to identify and realists' stances on morality are more nuanced than many detractors claim (Wilson 1998), the latter made the immorality and amorality of international relations a core feature of their approach. Morgenthau, for example, suggested that "universal moral principles cannot be applied to the actions of states" $(1985,12)$, while Carr famously argued that "ethics are a function of politics" $(1939,54)$, used as a pretext to justify power.

The debate between realists and liberals was partly explanatory in character. Liberals pointed to the potential role that morality might actually play in international politics by documenting, for instance, the development of international norms against particular forms of warfare or the role played by humanitarianism in foreign policy decision making (Lumsdaine 1993). However, theoretical differences over the nature of international politics often obscured that the realists and liberal idealists were at the same time engaged in a prescriptive argument over the role that morality should play in foreign affairs. Realists maintained that ethical questions should not intrude in foreign policymaking while at the same time claiming that they did not (Jervis 1994). This was particularly the case in discussions of American foreign policy. Kennan (1951) lamented the "legalistic-moralistic" tendency in American diplomacy, while Morgenthau pronounced "intoxication with moral abstractions" to be "one of the great sources of weakness and failure in American foreign policy" (1951, 4). This pattern has continued to the present day, with realists lamenting the role played by liberal thinking in the making of American policy while simultaneously claiming that American decision makers do not fall under its influence (Desch 2003; Mearsheimer 2001).

The role that public opinion should play in American foreign policymaking is also implicated in this debate, given that the mass public is seen by both realists and liberals as introducing ethical considerations, for better or for worse (Holsti 1992, 3). Drezner notes that "Realists and non-realists alike 
accept Louis Hartz's supposition that the Lockean worldview has an ideological chokehold over the American body politic" (2008, 51). The American public is seen as particularly idealistic and moralistic in its foreign policy preferences, owing largely to its liberal political origins (Lipset 1988).

For realists concerned about the moralist reductionism of "the popular mind," public opinion at its best forces decision makers to obfuscate the true nature of American foreign policy. Because interestbased arguments about the balance of power are insufficient for mobilizing popular support, Carr, like Mearsheimer $(2001,26)$, noted the "necessity, recognized by all politicians ... for cloaking interests in a guise of moral principles" $(1939,117)$. At its worst, public opinion leads the statesman down inadvisable paths. Christensen (1996) argues that the use of ideological and moral argumentation to rouse public opinion during the Cold War subsequently forced leaders to escalate the conflict further than the calculating realist would have recommended. Realists often caution against the dangers of moralizing foreign policy. Indeed, Morgenthau's first rule of diplomacy is to divest it of the "crusading spirit" $(1985,584)$. "Political realism," Morgenthau writes, "refuses to identify the moral aspirations of a particular nation with the moral laws that govern the universe" (quoted in Jervis 1994, 867). The influence of morality on foreign policy leads to dogmatism, making it particularly difficult to resolve conflicts of importance to the state. A prerequisite for avoiding this pitfall is a commitment to another principle: that the "government is the leader of public opinion, not its slave" (Morgenthau 1985, 591).

For liberal idealists, the public has a largely beneficial influence on foreign policy. Much liberal thinking on international relations stresses the selfinterest of ordinary citizens in peace, something that they are able to express in a democratic but not an autocratic system (Kant 1970; Owen 1994). However, liberal faith in the public has a deeper cause. Liberals believe that the masses are capable of a reasoned consideration of international politics (Holsti 1992). Wilson summarizes: "[T]he central idealist assumption is that human beings are rational, intelligent, creatures capable of recognizing the good and willing to implement it purely on the strength of its moral worth or intellectual merit" $(1998,8)$. This belief in the compelling power of reason was, in Carr's estimation, then "uncritically reproduced in the sphere of international politics" (1939, 31).

Realists, in contrast, believe that the mass public is emotional and therefore irrational, lacking the expertise and judgment necessary to form considered opinions on foreign affairs. Morgenthau writes that this is "especially" the case "when foreign policy is conducted under conditions of democratic control and is inspired by the crusading zeal of a political religion" (1985, 591). This sentiment dovetailed with the "Almond-Lippmann" consensus on American public opinion that emerged in the early postwar period, which saw the mass public as motivated by passion rather than reason, reaching judgments not based on calculations of national interest, but affective attachments towards particular countries (Holsti 1992, 3-7, 52). Carr describes what Wilson called "plain men throughout the world" as "a disorderly mob emitting incoherent, unhelpful noises" $(1939,14)$. Less stridently, Christensen recently writes that the public "simply does not have the time or expertise to understand the subtleties of balanceof-power politics" $(1996,7)$.

In this conception, emotions lead to erratic and short-term thinking in foreign affairs and serve as a source of inconsistency rather than structure. Lippmann describes the public as having "compelled the government, which usually knew what would have been wiser, or was necessary, or what was more expedient, to be too late with too little, or too long with too much, too pacifist in peace and too bellicose in war, too neutralist or appeasing in negotiations or too intransigent" $(1955,20)$. Kennan offered a similar view in his famous comparison of democratic publics to "one of those prehistoric monsters with a body as long as this room and a brain the size of a pin," largely inattentive to the world around him, until he awakens and "lays about him with such blind determination that he not only destroys his adversary but largely wrecks his native habitat" (1951, 59; see also Morgenthau 1985, 168).

We argue that the historical framing of the role of morality in American foreign policymaking is misguided in two ways. First, it presumes that the moral values that matter are always liberal in nature, neglecting other possible sets of moral foundations relevant to foreign affairs that are not based upon Enlightenment thinking. This sets up an impoverished cleavage between realist amoralism (or immoralism) and liberal moralism. Second, it assumes that if emotions influence foreign policy attitude formation in the mass public, their attitudes will be inconsistent. We must, however, leave open the possibility that individuals have predictable responses to foreign affairs that are rooted in moral impulses. Indeed, the literature on the ideological origins of foreign policy attitudes has largely abandoned the Almond-Lippmann consensus, finding that individuals are led by core beliefs towards 
predictable views on international affairs, which in turn are used as heuristics to form judgments on specific foreign policy issues (Hurwitz and Peffley 1987; Rathbun 2007). Even if the mass public is not up to date on developments in world politics, citizens have "postures," "dispositions," or "orientations" that consistently inform their attitudes towards more discrete issues in international relations (Herrmann, Tetlock, and Visser 1999; Hurwitz and Peffley 1987). Foreign policy beliefs in the mass public are thus ideological, if not unidimensional, in nature, in which "a few crowning postures... serve as a sort of glue to bind together many more specific attitudes and beliefs, and these postures are of prime centrality in the belief system as a whole" (Converse 1964, 211).

Realists use morality and ideology almost synonymously as threats to rational decision making. It may be, however, that like ideology, morality acts as a systematic rather than stochastic predictor of foreign policy attitudes. Any inconsistency we see in the public as a whole is a function of treating them as monolithic rather than as a collection of individuals with different moral foundations. A rigorous answer to these questions requires an investigation of individual attitudes towards foreign affairs based on a comprehensive framework of moral values, the task to which we now turn.

\section{Moral Foundations Theory}

Despite the central role played by morality in early debates in international relations theory, moral values have received strikingly little attention by public opinion scholars. Foreign policy attitudes are often viewed as the expression of more fundamental values-whether deemed "core values" (Hurwitz and Peffley 1987; Rathbun 2007), "core dispositional values" (Herrmann, Tetlock, and Visser 1999), or "core credos" (Nincic and Ramos 2011) - but as Murray and Cowden $(1999,458)$ note, this research largely proceeds inductively, inferring values from patterns of data rather than specifying a systematic theory of morals, measuring them, and testing for their effect ex ante. Hurwitz and Peffley (1987) do take a deductive approach, positing a model of "vertical" constraint in which abstract values (such as the morality of force) shape more specific attitudes on policy issues (such as defense spending), but the particular values they select-ethnocentrism and the morality of force-lack broader theoretical foundations. Their selection is largely ad hoc and their effect is assumed to be confined to the foreign policy domain.

To address this concern, we turn to the Moral Foundations Theory (MFT) framework developed by Jonathan Haidt and colleagues, who point to a finite number of discrete "moral foundations" that form distinct moral profiles while accounting for cultural and individual variation (Graham, Haidt, and Nosek 2009; Haidt, Graham, and Joseph 2009). All moral systems provide the same function: they are "interlocking sets of values, practices, institutions and evolved psychological mechanisms that work together to suppress or regulate selfishness and make social life possible" (Graham, Haidt, and Nosek 2009, 1030). However, they do so in different ways by emphasizing different principles of right and wrong behavior. MFT stands as the most prominent theory of moral values in psychology today. While other theoretical taxonomies of values enjoy widespread recognition in the discipline (e.g., Schwartz 1994), Haidt's work limits itself specifically to moral values rather than entire value systems. Moral values have been implicated in a diverse array of phenomena, from political ideology (Graham, Haidt, and Nosek 2009) to psychopathy (Glenn et al. 2010), and the theory is widely employed across subfields of psychology.

We focus on MFT for three reasons. First, it provides a unified framework for thinking about the origins of foreign policy attitudes. As Mondak (2010) argued about the state of personality research prior to the development of the "Big 5," value researchers are confronted with a cornucopia of values from which to choose (Inglehart 1997; Schwartz 1994); the Rokeach (1973) value survey alone, for example, contains 36 different values. In IR, scholars have embraced a wide range of values as predictors of foreign policy attitudes, such as punitiveness (Liberman 2006), ethnocentrism and the morality of warfare (Hurwitz and Peffley 1987), and hierarchy and community (Rathbun 2007). The advantage of MFT is that it provides us with a unified framework that is both comprehensive and parsimonious. Second, classical arguments about public opinion in IR were not about values in general, but moral values in particular. Moral Foundations Theory allows us to address these claims head on. Third, MFT has been tested in the political realm, and moral values have been found to predict domestic political attitudes (Federico et al. 2013; Graham, Haidt, and Nosek 2009).

Moral Foundations Theory identifies five different moral foundations-harm/care, fairness/reciprocity, authority/respect, purity/sanctity, and ingroup/loyalty. 
The first two are "individualizing foundations," which form the backbone of liberal philosophical thinking dating to the Enlightenment, in which morality is "about how well or poorly individuals treated other individuals" (Graham et al. 2011, 366). Harm/care is a concern for the suffering of others, including virtues of caring and compassion; caring for others and protecting them are good behaviors in this system. It is driven by altruistic, other-regarding behavior. Under the moral foundation of fairness/reciprocity, individuals should be treated equally; to deny a person such equality is to treat them unfairly and unjustly (Graham, Haidt, and Nosek 2009). Liberal theorists maintain that treating others with "equal concern and respect" is at the heart of the democratic project of valuing individuals (Howard and Donnelly 1986).

The other three are "binding foundations." Authority/respect concerns the maintenance of social hierarchies to assure social order, highlighting obedience, respect, and role fulfillment. Ingroup/loyalty stresses individuals' obligations to their group so as to preserve its cohesion, particularly against outgroups. Purity/sanctity entails admonitions to maintain bodily and spiritual cleanliness. These moral systems serve the same function as the others-constraining self-interested action to benefit society as a whole-but they do so by subordinating individual needs to the larger community's needs.

Importantly, Haidt (2001) argues that moral judgments are not based on the rationalist decisionmaking process proposed in early work on moral development (Turiel 1983). Those approaches suggest that morals are used as part of a considered reasoning process, in which one "briefly becomes a judge," and only after assessing the issues at stake makes a determination about the moral status of a situation (Haidt 2001, 814). Haidt's (2001) social intuitionist model argues, in contrast, that detailed moral reasoning is often the effect, rather than the cause, of moral judgments. Moral judgments are the consequence of an intuitive "gut response" to a situation, making them more akin to unconscious, automatic, emotional, or perceptual processes than the deliberative reasoning previously expected. Moral deliberation and reasoning, to the extent that it occurs, follows the intuitive choice. Thus, while an individual's configuration of moral values is a consistent predictor of important attitudes, morality has an emotional foundation (Graham, Haidt, and Nosek 2009).

A strong emphasis of Haidt and his colleagues has been that the binding foundations deserve equal status as moral foundations with the individualizing foundations. They find that the latter have been the dominant way of thinking about what constitutes moral behavior in the literature on moral values, which has had the effect of crowding out other ways of understanding ethical behavior. While a few have pointed out that even realism has a hidden moralism (Murray 1996a), American IR theorists have largely been moral "monists," equating morality solely with liberal considerations about fairness and harm. MFT emphasizes thinking pluralistically about morality, asserting that there is not a single dimension of moral concern (Graham et al. 2013).

\section{Theoretical Expectations}

We expect that distinct configurations of the five moral foundations shape public opinion about foreign policy, with cooperative and self-interested attitudes alike grounded in morality. We use Moral Foundations Theory to predict individuals' foreign policy orientations as well as a number of specific policy positions and contextualize these relationships in terms of IR theory. We measure the former using the canonical cooperative internationalism/militant internationalism framework. Largely on the basis of work done by Wittkopf (1990) and Holsti and Rosenau (1990), scholars have settled on the notion that there are two fundamental "postures" towards international affairs, labeled by Wittkopf (1990) as "cooperative internationalism" (CI) and "militant internationalism" (MI). This widely used framework is described as the "gold standard" (Nincic and Ramos 2011, 122) and the "most influential" (Murray and Cowden 1999, 458) way of conceptualizing the structure of foreign policy thinking. Following others, we also include a third isolationist dimension generally found to supplement rather than displace the other two (Chittick, Billingsley, and Travis 1995; Rathbun 2007). While early studies assumed that $\mathrm{CI}$ and MI were orthogonal to one another, subsequent research consistently shows them to be negatively correlated (Murray 1996b; Rathbun 2007).

CI captures the distinction between the self and other in international affairs: what Chittick, Billingsley, and Travis (1995) call "a concern for the wider community," and Nincic and Ramos (2011) call "other-regarding" objectives. Both studies see a continuum marked by an exclusive concern for the national interest on the one side and a more inclusive, globalist, and cosmopolitan agenda on the other. Individuals who score high on CI typically believe that the United States should work with other countries and international organizations to solve global problems. 
MI, in contrast, marks the familiar division between hawks and doves over the importance, effectiveness, and/or desirability of using force to reach foreign policy objectives. Hawks, embracing the "deterrence model," believe that peace is best achieved through strength and the demonstration of resolve. Doves, in contrast, are more likely to embrace the "spiral model," pointing out the often self-defeating nature of such displays as they incite fear and escalate hostilities (Jervis 1976). Even those who do not directly embrace the CI/MI framework make use of this distinction. Hurwitz and Peffley use a "dimension of militarism .... anchored, on the one end, by a desire that the government assume an assertive, militant foreign-policy posture through military strength and on the other by a desire for a more flexible and accommodating stance through negotiations" (1987, 1107). Both Nincic and Ramos (2011) and Chittick and Billingsley (1989) describe it as instrumental in nature. The latter write of the "various means of accomplishing foreign policy goals," which are captured by positions on the MI dimension (Chittick and Billingsley 1989, 219). Nincic and Ramos (2011) describe an ideological divide over the utility of positive versus negative incentives.

Liberal idealism in international affairs entails an emphasis on CI. Those who trace the origins of liberal idealist thinking in IR note its embrace of humanitarianism and multilateralism (Drezner 2008). This way of thinking is also marked by a general resistance to MI, as liberal idealists maintain that reasoned individuals are capable of resolving their disputes peacefully. Nevertheless, scholars frequently point out how liberal idealists are often overly eager to wield the sword when it comes to using force to pursue interests close to their heart, such as democracy or the protection of human rights, which are part of core CI instincts (Desch 2003; Doyle 1986; Rathbun 2007).

We expect that high values of $\mathrm{CI}$ and low values of MI are predicted by the individualizing moral foundations (harm/care and fairness/reciprocity). Indeed, international relations scholars have said as much previously, long before the advent of Moral Foundations Theory (Carr 1939; Herz 1950). Osgood notes that for liberal idealists, "the ultimate moral value is the innate dignity and worth of every human being," who has "certain inalienable rights of selfprotection and self-expression... The ultimate moral standard remains the individual's welfare" $(1953,7)$. Herz writes that liberal idealism is based on individualist ideas "in favor of limiting... the power and authority which organized groups claim over men" $(1950,159)$. Carr (1939) explains that liberal idealism is based on the idea of equality between members of a community and the principle that the good of the whole takes precedence over the good of the part. This describes fairness/reciprocity and harm/care, respectively.

Concern for the individual and commitment to equal treatment is fundamental for liberal idealists and those who value CI. Osgood writes that "the realization of the liberal and humane values" of idealists requires "the creation of a brotherhood of mankind in which all men ... have equal partnership and in which human conflicts will be settled by reason, morality and law rather than by physical power, coercion or violence" $(1953,7)$. The individualizing foundations thus should predict support for CI. Multilateralism rests on the equality of states, who act together to reach agreements that are in their mutual interest, while international cooperation provides care for others.

We also expect a negative relationship between the individualizing foundations-particularly harm/careand MI insofar as the use of force involves the subordination of others' interests and even implies their subjection to physical violence. However, this link is less direct than to CI. Since MI seems to be a defensive orientation rather than one that consciously denigrates the interests of others or means them harm, we expect that relationship between the individualizing foundations and MI to be weaker than that with CI.

Despite the novelty of using MFT to systematically ground these foreign policy orientations, this account is nonetheless consistent with the liberal manner in which IR theorists have tended to understand morality. However, since the individualizing foundations do not exhaust the moral systems that we see in the world, it should also be the case that illiberal foreign policy postures also have moral foundations. The binding foundations - which serve the function of protecting the group from threats both inside and outsideshould therefore also play a role in foreign policy attitudes, predicting low values of $\mathrm{CI}$ and high values of MI. Strong deference to authority is necessary so that those charged with acting on behalf of the group can act decisively to neutralize threats to society. Loyalty to the ingroup is necessary to provide the requisite solidarity to keep society internally stable and to endure in the face of external aggression. Purity, with its emphasis on traditional values and disgust for those who do not conform to cultural standards of decency, also revolves around protecting society from threats. Those who value purity are more likely to experience disgust and thus to dehumanize members of 
outgroups-facilitating support for the use of violence against foreigners (Buckels and Trapnell 2013). Since MI is characterized by a readiness to act with force to protect the nation, we expect a particularly strong relationship between the binding foundations and MI.

We also hypothesize a weaker and less direct relationship between the binding foundations, particularly ingroup/loyalty, and CI. Given the inward and defensive orientation of those with a strong commitment to these values, this might come at the expense of a concern for broader global problems, expressed in low levels of CI. However, we should not presume that such binding implies absolute antipathy and hostility to outsiders as an end in itself: ingroup loyalty is not the same as outgroup hostility, even if the two are likely related (Brewer 1999).

The binding foundations likely underlie the position taken by what Mead calls "Jacksonians" in foreign policy. In Special Providence: American Foreign Policy and How it Changed the World, Mead (2002) identifies a number of traditions in American foreign policy thinking, highlights their core principles, and traces their influence historically on U.S. relations with the rest of the world. While they share realists' disapproval of liberal foreign policy and its pursuit of idealistic ends, Jacksonians have their own moralistic streak, supporting aggressive military force, preemptive wars, and subversive tactics against bad governments (Mead 2002, 24). This is as driven by national security concerns as it is with maintaining the honor of the United States; Mead $(2002,246)$ cites an "honor code" that includes obligations to protect others. The cowboy has a moral code-just a different one than Woodrow Wilson. We refer to this combination of low CI and high MI as a "hardliner" approach, as compared to a "softliner" combination of high CI and low MI characteristic of liberal idealists.

While we argue that support for aggressive approaches to foreign policy is morally grounded, we do expect that one orientation will be largely amoral, at least in terms of the moral foundations articulated by Haidt (2007): isolationism. Isolationists have a general preference for disengagement, a tendency manifested in opposition to both foreign military interventions and the projection of American force constitutive of MI, as well as hostility to globalist policies such as humanitarian aid and multilateral cooperation characteristic of CI (Wittkopf 1990). However, isolationism has repeatedly been found to be a separate third dimension structuring foreign policy attitudes at both the mass and elite levels (Chittick, Billingsley, and Travis 1995; Rathbun 2007). While isolationism is negatively correlated with CI and MI, it is not reducible to these constructs. For instance, those who oppose globalization because of its effect on the poor abroad or those who rally against American military intervention for the damage it causes to innocent civilians are isolationist by outcome rather than principle. Such individuals, high on CI, would support action to improve the lives of those abroad while genuine isolationists would be resistant. This viewpoint seems to indicate a general resistance to social engagement of any kind, whether it be of self-righteous superiority and imperialism or idealistic concern. Given that all the moral foundations govern how individual units interact with broader social groupings because, as Haidt $(2007,999)$ writes, "moral thinking is for social doing," we hypothesize that the moral foundations will not be strong predictors of isolationism (see also Iyer et al. 2012).

It might be, however, that isolationism is a product of a different moral foundation not originally included in Haidt's (2007) framework. In particular, isolationists might score high on a concern for liberty, which has recently been raised as a candidate for a moral foundation (Iyer et al. 2012). There is a natural coherence between a commitment to self-reliance and individualism at home and disengagement abroad. Traditional isolationists in the nineteenth and early twentieth century, sometimes called Jeffersonians, were deeply opposed to the centralized state, something that has been largely forgotten (Mead 2002). Libertarians have been found not to score highly on any of the five moral foundations, feel less emotional connection to others, and value most highly individual autonomy (Iyer et al. 2012). While Haidt's (2007) original framework does not include liberty, there are other indirect ways of measuring libertarianism as a moral value discussed below.

\section{Methods}

We explore these questions with data gathered in the spring of 2012 on YourMorals.org, an online platform created to collect data on moral foundations, where participants register to complete a variety of questionnaires that shed light on a range of personality traits, moral values, and individual differences. Upon completing a study, participants are able to compare their own scores to others who have completed the survey. Participants typically find the website through news articles about psychological research or by typing words related to morality into a search engine. 
Although largely foreign to political scientists, the YourMorals platform has been central to both the testing and development of MFT in social psychology (e.g., Graham, Haidt, and Nosek 2009) and its application to a variety of domains (e.g., Donnelly, Iyer, and Howell 2012; Iyer et al. 2012).

Since our data come from an opt-in survey, it is important to note that the sample is not representative of the American population as a whole. However, we argue that it is nonetheless valuable for our purposes, for four reasons. First, as we show in online Appendix $\S 3.1$, we employ entropy balancing (Hainmueller 2012) to reweight the data to known population parameters and find that the substantive results do not change, suggesting that the findings are robust to the demographic composition of the sample. Second, other research conducted on the YourMorals platform has been replicated on nationally representative samples (Smith and Vaisey 2010) and in a series of robustness checks in online Appendix §3.2-3.3, we show that neither our participants' foreign policy attitudes nor their moral values systematically differ from data gathered in representative samples, including one fielded on YouGov/Polimetrix by Gries (2014).

Third, the self-selected nature of the sample actually increases data quality: compared to nationally representative samples, volunteer samples are typically more intrinsically motivated, producing cleaner data that display less measurement error, satisficing, and social desirability bias (Chang and Krosnick 2009). Fourth, the use of a data collection platform with motivated respondents - who are participating for the educational benefit of learning about how their foreign policy and moral attitudes are classified-allows us to employ lengthier scales for measuring our variables of interest, thereby increasing construct validity and decreasing measurement error (Ansolabehere, Rodden, and Snyder 2008). In short, we believe our data offer an intriguing first take on the relationship between moral values and foreign policy attitudes, and we encourage other researchers to build on these findings on both American and non-American samples.

The foreign policy instrumentation consisted of 20 questions, listed in online Appendix $\S 1$. A six-item scale measuring MI and five-item scale measuring CI contained standard items from Wittkopf (1990), dropping those specific Cold War policy items that may no longer be relevant to present-day respondents. The six MI items $(\alpha=0.84)$ tap into participants' views about the use of American military might abroad, asking generally whether war and the use of force are potentially beneficial and whether the United States needs to demonstrate its might and resolve.
The five CI items $(\alpha=0.88)$ ask participants about the importance of working with other countries or organizations like the United Nations to solve transnational problems (including human rights violations, poverty, and protecting the global environment). A standard five-item isolationism scale $(\alpha=0.78)$ assessed participants' impressions of whether the United States should concentrate on domestic problems, scale back its global leadership, and generally stay out of other countries' problems. Finally, four policy-specific questions measured participant attitudes toward the 2011 air strikes in Libya, the potential for using force against a nuclear Iran, the U.S. war in Iraq, and the United States working with other countries to renew the Kyoto Protocol.

The moral foundations were measured using the questionnaire developed by Haidt and his colleagues (Graham, Haidt, and Nosek 2009), presented in online Appendix $\S 2$. In it, participants record how relevant considerations are to their judgments of right and wrong on a 6-point scale from "not at all relevant" to "extremely relevant" and the extent to which they agree with statements about the importance of each value on a 6-point scale from "strongly disagree" to "strongly agree."

In total, 2,300 participants completed our foreign policy survey using the YourMorals platform. The sample is truncated for analysis in two ways. First, because of our focus on the foreign policy attitudes of the American public, we drop those participants who report that they currently reside outside of the United States $(\mathrm{N}=297)$, leaving a sample of 2,003 American participants. Second, the YourMorals platform saves participants from lengthy sittings by allowing them to complete surveys separately, thereby enabling researchers to compile data across different domains. Because an analysis of the theory's predicted connections between moral foundations and foreign policy attitudes requires that we obtain measures of both for each participant, our main analyses thus focus on the subset of American participants who completed both the foreign policy and moral foundations questionnaires.

\section{Results}

\section{Nonidealists Have Morals Too}

We begin with Models 1, 4, and 7 of Table 1, which estimate the impact of the five moral foundations on $\mathrm{CI}, \mathrm{MI}$, and isolationism, respectively, operationalized using factor scores to obtain more precise estimates of 
TABle 1 Foreign Policy Batteries

\begin{tabular}{|c|c|c|c|c|c|c|c|c|c|}
\hline & \multicolumn{3}{|c|}{ Cooperative Internationalism } & \multicolumn{3}{|c|}{ Militant Internationalism } & \multicolumn{3}{|c|}{ Isolationism } \\
\hline & (1) & $(2)$ & (3) & $(4)$ & (5) & $(6)$ & (7) & (8) & (9) \\
\hline Harm & $\begin{array}{l}0.604^{\star * *} \\
(0.039)\end{array}$ & $\begin{array}{l}0.603^{\star * *} \\
(0.040)\end{array}$ & $\begin{array}{l}0.417^{\star * *} \\
(0.038)\end{array}$ & $\begin{array}{l}-0.352^{\star * *} \\
(0.034)\end{array}$ & $\begin{array}{l}-0.325^{\star * *} \\
(0.035)\end{array}$ & $\begin{array}{l}-0.230^{* * *} \\
(0.036)\end{array}$ & $\begin{array}{l}-0.150^{\star * \star} \\
(0.043)\end{array}$ & $\begin{array}{l}-0.171^{\star * *} \\
(0.045)\end{array}$ & $\begin{array}{l}-0.096^{\star *} \\
(0.047)\end{array}$ \\
\hline Fairness & $\begin{array}{l}0.419^{\star * *} \\
(0.045)\end{array}$ & $\begin{array}{l}0.419^{\star * *} \\
(0.045)\end{array}$ & $\begin{array}{l}0.168^{\star * \star} \\
(0.043)\end{array}$ & $\begin{array}{l}-0.122^{\star * \star} \\
(0.039)\end{array}$ & $\begin{array}{l}-0.132^{\star * *} \\
(0.039)\end{array}$ & $\begin{array}{c}0.005 \\
(0.040)\end{array}$ & $\begin{array}{l}-0.019 \\
(0.050)\end{array}$ & $\begin{array}{l}-0.004 \\
(0.050)\end{array}$ & $\begin{array}{c}0.093^{\star} \\
(0.052)\end{array}$ \\
\hline Ingroup & $\begin{array}{l}-0.190^{\star * *} \\
(0.043)\end{array}$ & $\begin{array}{l}-0.188^{\star * *} \\
(0.043)\end{array}$ & $\begin{array}{l}-0.085^{\star \star} \\
(0.039)\end{array}$ & $\begin{array}{l}0.360^{\star * *} \\
(0.038)\end{array}$ & $\begin{array}{l}0.347^{\star * *} \\
(0.038)\end{array}$ & $\begin{array}{l}0.276^{\star * *} \\
(0.037)\end{array}$ & $\begin{array}{l}-0.118^{\star \star} \\
(0.049)\end{array}$ & $\begin{array}{l}-0.112^{\star \star} \\
(0.049)\end{array}$ & $\begin{array}{l}-0.116^{\star *} \\
(0.049)\end{array}$ \\
\hline Authority & $\begin{array}{l}-0.082^{\star} \\
(0.046)\end{array}$ & $\begin{array}{l}-0.082^{\star} \\
(0.046)\end{array}$ & $\begin{array}{l}-0.081^{\star \star} \\
(0.041)\end{array}$ & $\begin{array}{l}0.222^{\star * *} \\
(0.040)\end{array}$ & $\begin{array}{l}0.225^{\star * *} \\
(0.040)\end{array}$ & $\begin{array}{l}0.203^{\star * *} \\
(0.039)\end{array}$ & $\begin{array}{l}-0.141^{\star * \star} \\
(0.051)\end{array}$ & $\begin{array}{l}-0.126^{\star *} \\
(0.051)\end{array}$ & $\begin{array}{l}-0.087^{\star} \\
(0.051)\end{array}$ \\
\hline Purity & $\begin{array}{l}-0.153^{\star * \star} \\
(0.033)\end{array}$ & $\begin{array}{l}-0.155^{\star \star *} \\
(0.033)\end{array}$ & $\begin{array}{l}-0.056^{\star} \\
(0.031)\end{array}$ & $\begin{array}{l}0.182^{\star * *} \\
(0.029)\end{array}$ & $\begin{array}{l}0.188^{\star * *} \\
(0.029)\end{array}$ & $\begin{array}{l}0.079^{* * *} \\
(0.030)\end{array}$ & $\begin{array}{c}0.019 \\
(0.037)\end{array}$ & $\begin{array}{c}0.021 \\
(0.037)\end{array}$ & $\begin{array}{c}0.056 \\
(0.039)\end{array}$ \\
\hline Age & & $\begin{array}{l}-0.0002 \\
(0.0004)\end{array}$ & $\begin{array}{c}0.0002 \\
(0.0003)\end{array}$ & & $\begin{array}{l}-0.0001 \\
(0.0003)\end{array}$ & $\begin{array}{l}-0.0004 \\
(0.0003)\end{array}$ & & $\begin{array}{l}-0.001^{\star} \\
(0.0004)\end{array}$ & $\begin{array}{l}-0.001 \\
(0.0004)\end{array}$ \\
\hline Male & & $\begin{array}{l}-0.011 \\
(0.014)\end{array}$ & $\begin{array}{c}0.023^{\star} \\
(0.012)\end{array}$ & & $\begin{array}{l}0.038^{\star * *} \\
(0.012)\end{array}$ & $\begin{array}{l}0.029^{\star *} \\
(0.012)\end{array}$ & & $\begin{array}{l}-0.021 \\
(0.015)\end{array}$ & $\begin{array}{l}-0.035^{\star *} \\
(0.015)\end{array}$ \\
\hline High School & & $\begin{array}{l}-0.047 \\
(0.045)\end{array}$ & $\begin{array}{l}-0.058 \\
(0.041)\end{array}$ & & $\begin{array}{l}-0.024 \\
(0.039)\end{array}$ & $\begin{array}{l}-0.006 \\
(0.039)\end{array}$ & & $\begin{array}{l}0.117^{\star \star} \\
(0.050)\end{array}$ & $\begin{array}{l}0.144^{* * *} \\
(0.051)\end{array}$ \\
\hline Some college & & $\begin{array}{c}0.011 \\
(0.031)\end{array}$ & $\begin{array}{c}0.013 \\
(0.030)\end{array}$ & & $\begin{array}{l}-0.001 \\
(0.028)\end{array}$ & $\begin{array}{c}0.001 \\
(0.028)\end{array}$ & & $\begin{array}{c}0.024 \\
(0.035)\end{array}$ & $\begin{array}{c}0.052 \\
(0.037)\end{array}$ \\
\hline College/university & & $\begin{array}{c}0.021 \\
(0.031)\end{array}$ & $\begin{array}{c}0.027 \\
(0.029)\end{array}$ & & $\begin{array}{l}-0.014 \\
(0.027)\end{array}$ & $\begin{array}{l}-0.006 \\
(0.028)\end{array}$ & & $\begin{array}{c}0.011 \\
(0.035)\end{array}$ & $\begin{array}{c}0.042 \\
(0.037)\end{array}$ \\
\hline Grad/prof school & & $\begin{array}{c}0.051 \\
(0.031)\end{array}$ & $\begin{array}{c}0.032 \\
(0.030)\end{array}$ & & $\begin{array}{l}-0.026 \\
(0.028)\end{array}$ & $\begin{array}{l}-0.006 \\
(0.028)\end{array}$ & & $\begin{array}{l}-0.013 \\
(0.036)\end{array}$ & $\begin{array}{c}0.025 \\
(0.037)\end{array}$ \\
\hline Liberal & & & $\begin{array}{l}0.097^{\star * \star} \\
(0.020)\end{array}$ & & & $\begin{array}{l}-0.050^{* * *} \\
(0.019)\end{array}$ & & & $\begin{array}{l}-0.047^{\star} \\
(0.025)\end{array}$ \\
\hline Conservative & & & $\begin{array}{l}-0.176^{\star * *} \\
(0.022)\end{array}$ & & & $\begin{array}{l}0.155^{\star * \star} \\
(0.021)\end{array}$ & & & $\begin{array}{l}-0.047^{\star} \\
(0.027)\end{array}$ \\
\hline Libertarian & & & $\begin{array}{l}-0.197^{\star * *} \\
(0.021)\end{array}$ & & & $\begin{array}{l}0.051^{\star *} \\
(0.020)\end{array}$ & & & $\begin{array}{l}0.144^{\star * *} \\
(0.026)\end{array}$ \\
\hline Constant & $\begin{array}{l}0.117^{\star \star *} \\
(0.034)\end{array}$ & $\begin{array}{l}0.107^{\star *} \\
(0.047)\end{array}$ & $\begin{array}{l}0.309^{\star * *} \\
(0.048)\end{array}$ & $\begin{array}{l}0.459^{\star * *} \\
(0.030)\end{array}$ & $\begin{array}{l}0.442^{\star * \star} \\
(0.041)\end{array}$ & $\begin{array}{l}0.358^{\star * \star} \\
(0.045)\end{array}$ & $\begin{array}{l}0.760^{\star \star \star *} \\
(0.038)\end{array}$ & $\begin{array}{l}0.789^{\star * *} \\
(0.052)\end{array}$ & $\begin{array}{l}0.620^{\star * *} \\
(0.059)\end{array}$ \\
\hline $\mathrm{N}$ & 1,163 & 1,163 & 1,092 & 1,159 & 1,159 & 1,089 & 1,154 & 1,154 & 1,085 \\
\hline $\mathrm{R}^{2}$ & 0.491 & 0.497 & 0.635 & 0.489 & 0.495 & 0.558 & 0.046 & 0.063 & 0.164 \\
\hline Adjusted $\mathrm{R}^{2}$ & 0.489 & 0.492 & 0.630 & 0.487 & 0.491 & 0.552 & 0.042 & 0.054 & 0.153 \\
\hline
\end{tabular}

Note: Reference category for education: less than high school; For ideology: moderate. All variables scaled from 0 to 1 , except for age.

All analyses are unweighted; for weighted and other supplemental analyses, see Appendix $\S 3$ and $\S 6 .{ }^{\star} p<.1 ;{ }^{* *} p<.05 ;{ }^{* * *} p<.01$. 


\section{Figure 1 Coefficient Plots of Moral Foundations on Foreign Policy Attitudes}

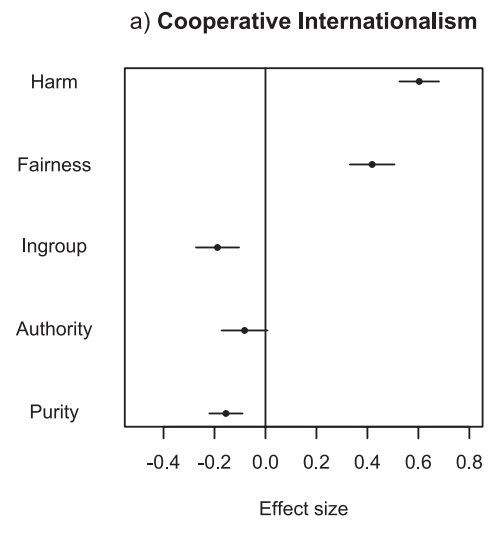

d) Iraq War

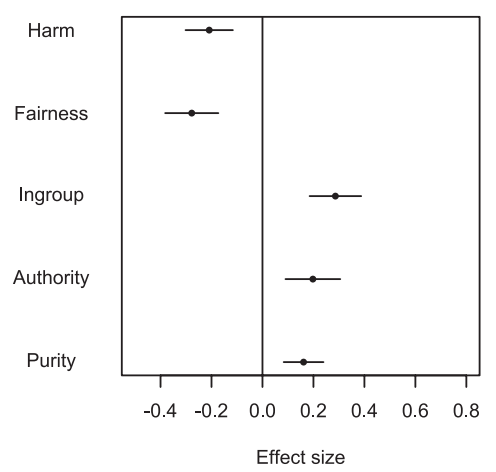

b) Militant Internationalism

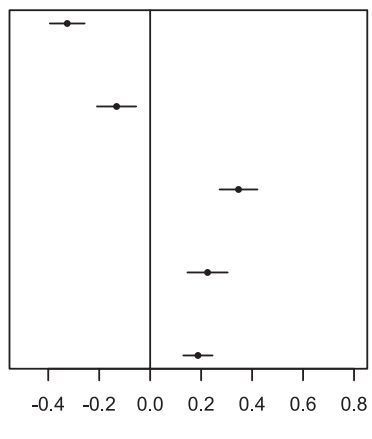

Effect size

e) Iran Strike

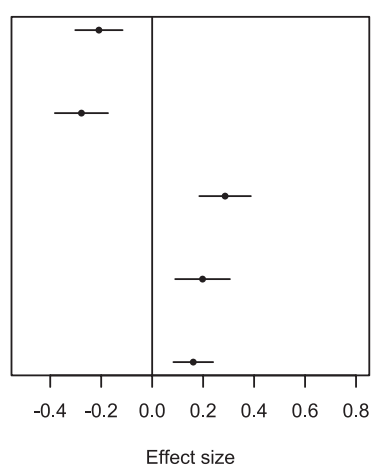

c) Isolationism

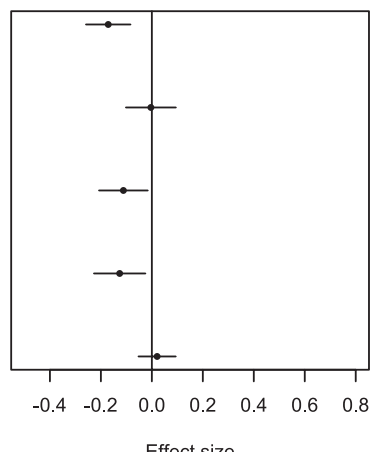

f) Kyoto Protocol

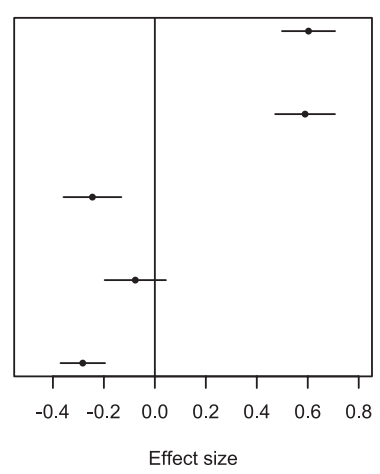

g) Libya Intervention

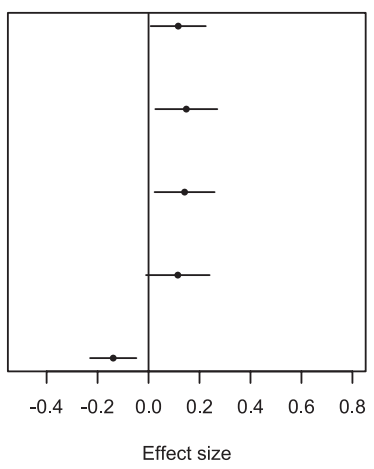

Note: Point estimates and $95 \%$ CIs for the effects of the moral foundations on foreign policy orientations (panels a-c) and specific foreign policy issues (panels d-g); the models also control for demographic characteristics, omitted from the figures for presentational purposes. All variables are scaled from 0 to 1 , so the point estimates represent the effect of moving from the minimum to the maximum value of each moral foundation.

the constructs of interest. ${ }^{2}$ The next set of models $(2,5$, and 8 ) probe the robustness of the results by adding control variables for demographic characteristics. Across both sets of models, the same story applies: $\mathrm{CI}$ and MI have strong moral foundations, while isolationism does not.

These results are best conveyed in Figure $1(\mathrm{a}-\mathrm{c})$, which visualizes the effect size of the moral foundations on foreign policy attitudes. Harm/care has a strong positive relationship with $\mathrm{CI}$ and a strong negative

\footnotetext{
${ }^{2}$ Factor-score regression is frequently used in survey research in political science (e.g., Ansolabehere, Rodden, and Snyder 2008); by allowing researchers to extract solely the dimension of interest, factor scoring allows for less noisy estimates that would arise from the use of additive scores that simply average across survey items. Principal-axis factoring was used to generate the scores for each of the three foreign policy orientation scales, which were then normalized to range from 0 to 1 to facilitate substantive interpretation of the results. Appendix $\S 6.1$ replicates these results using simple additive scores for the three dependent variables and shows the relationships remain the same-albeit with marginally smaller effect sizes, while online Appendix $\S 6.3$ calculates factor scores using an exploratory rather than a confirmatory approach.
}

relationship with MI: a 1-unit increase (moving from the minimum to the maximum value) in harm is associated with a 0.60 -unit increase in CI, and a 0.33-unit decrease in MI. Thus, the more an individual's moral foundations emphasize relieving harm and caring about the welfare of others, the more likely she is to support working with the international community to tackle issues like hunger and global warming and the less likely she is to support the use of force and believe that military strength is the best way to preserve peace. Fairness/reciprocity is similarly related to these foreign policy orientations: a 1-unit increase in fairness is associated with a 0.42-unit increase in CI and a 0.13-unit decrease in MI. Individuals that place a strong emphasis on equality, justice, and reciprocity are more likely to support promoting human rights and less likely to be concerned about demonstrating military resolve. Thus, respondents who are high in the two individualizing foundations are more likely to be "softliners" in their attitudes about American foreign policy.

Although the two individualizing foundations are the strongest predictors of $\mathrm{CI}$, the binding foundations 
also have significant effects. Individuals who venerate the ingroup are 0.19 units less supportive of $\mathrm{CI}$, while those who emphasized purity/sanctity are 0.16 units less supportive. Those individuals whose morals depend greatly on authority/respect are 0.08 units less supportive of CI, an effect that just narrowly escapes significance at the $p<0.05$ level. Thus, while CI is positively associated with the individualizing foundations, it is negatively associated with the binding ones: the less value individuals place on patriotism, deferring to authority, and expressing disgust, the more supportive they are of CI. While the binding foundations are negatively associated with CI, they are positively associated with MI. Substantively, the largest predictor of support for MI is ingroup/ loyalty: individuals who emphasize patriotism and group loyalty are 0.35 units more supportive of hawkish foreign policies. Authority/respect has a similar effect: individuals who emphasize obedience, duty, and tradition are 0.23 units more supportive of MI. Finally, although its substantive effect is half that of ingroup/ loyalty, purity/sanctity also predicts MI, corresponding with a 0.19 -unit increase. Those individuals who view certain activities as unnatural or degrading are slightly more likely to support the use of the U.S. military abroad. This pattern in which individuals who place greater emphasis on the binding foundations are high in MI but low in CI suggests that they are more likely to be "hardliners" driven by national security concerns but stay out of the chaos when necessary.

Five points are worth making here. Most importantly, morality is not merely the domain of liberal idealists: CI is positively associated with the individualizing foundations and negatively associated with the binding foundations, whereas MI is negatively associated with the individualizing foundations and positively associated with the binding ones. In this sense, both $\mathrm{CI}$ and MI rely on moral foundations. Against the liberal assumptions that characterize understandings of morality in IR theory, we see that hawks have consistent moral foundations too. Second, although CI and MI rely on these opposing configurations of moral foundations, supplementary analyses in online Appendix $\S 4$ confirm that the two foreign policy orientations are in fact distinct dimensions and are not merely opposites of one another. Third, the effect of these moral foundations are substantively strong, featuring adjusted $R^{2}$ statistics unusually high ( 0.49 and 0.49 , respectively) for this type of survey data.

Fourth, although both MI and CI have strong moral foundations, isolationism appears to be divorced from Haidt's inventory of moral foundations: as Figure 1(c) shows, the effect sizes for isolationism are relatively small. The more individuals are concerned about whether others are being harmed, the less likely they are to express support for isolationism, but although harm/care represents the strongest effect size of any moral foundation on isolationism (a 0.17-unit decrease), it is relatively weak when compared to the effects of most of the moral foundations on CI and MI. Interestingly, although the isolationist calculus is often framed in terms of choosing to devote scarce resources to problems at home rather than abroad (Nincic 1997), respondents whose moral foundations emphasized the ingroup were less likely to be isolationist, an effect substantively similar to that of authority $(0.11$ and 0.13 units, respectively). In this respect, isolationism's relatively weak moral foundations suggest either that it may be better understood as a reaction to events in the world (Kertzer 2013) than as a morally grounded disposition, or that it is morally grounded, but not in the five moral foundations shown here-a possibility we explore below.

Fifth, since Graham, Haidt and Nosek (2009) find that liberals are high in the individualizing moral foundations while conservatives are high in both individualizing and binding foundations - and liberalism is associated with high levels of CI and low levels of MI-this pattern of results raise the specter that political ideology is driving the results (Holsti and Rosenau 1996; Murray 1996b). To rule out this possibility, we perform two tests. First, models 3, 6, and 9 replicate the previous set of analyses but also control for political ideology, operationalized here with a system of dummy variables both to model potential nonlinearity, and because unlike most ideology measures in political science, the survey's ideology measure included a "libertarian" option. As the results show, the moral foundations' effects persist, decreasing somewhat in magnitude but remaining statistically significant as well as substantively larger than the effects of ideology. This suggests that there is more to the previous set of results than simply that conservatives are high in MI and liberals high in CI. Importantly, libertarianism is positively associated with isolationism, as anticipated above. Thus, although we do not have a direct measure of endorsement for liberty, we have suggestive evidence that a commitment to individualism and self-reliance leads to foreign policy preferences for one's nation to do the same-suggesting an avenue for future research about the moral foundations of isolationism.

\section{Nonparametric mediation analyses}

That said, we have theoretical and empirical reasons to believe that moral foundations underlie political 
FIgURE 2 Nonparametric Mediation Analyses

a) Cooperative Internationalism

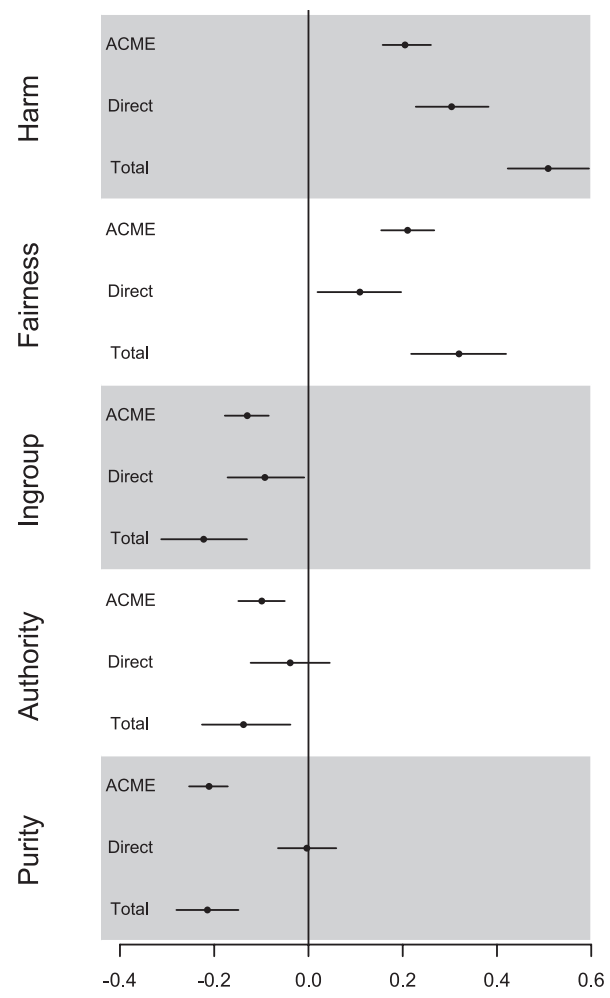

b) Militant Internationalism

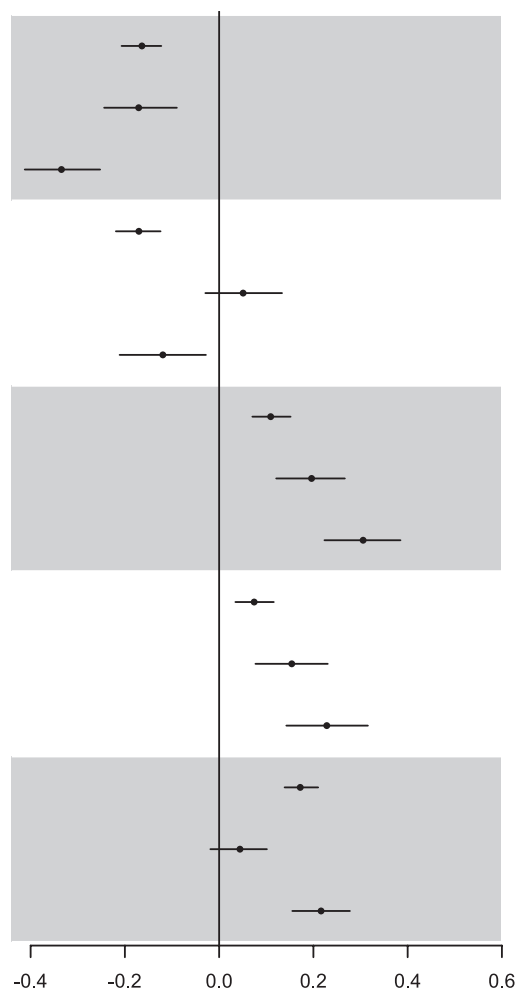

c) Isolationism

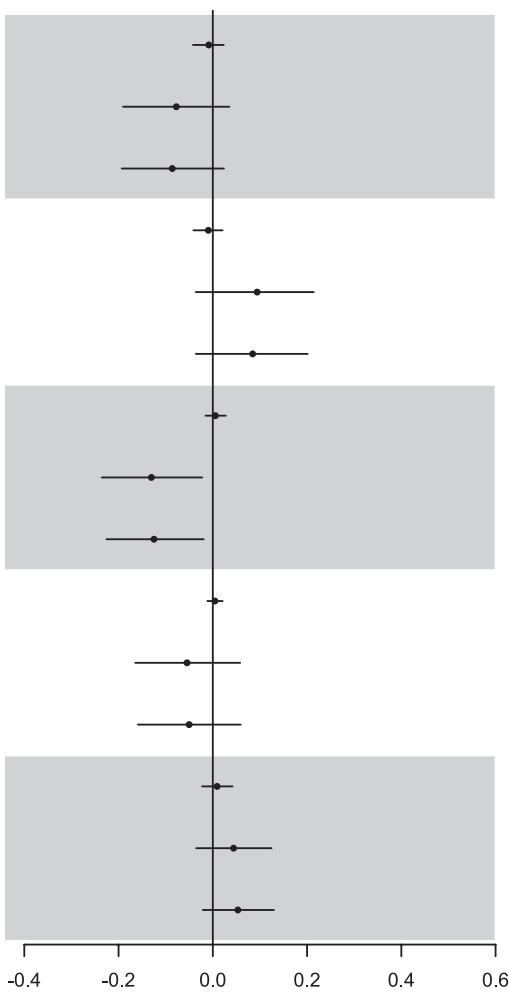

Note: Nonparametric mediation analyses (Imai et al. 2011) calculated using $\mathrm{N}=1500$ simulations and $95 \%$ quasi-Bayesian confidence intervals show that all five moral values' effect on cooperative internationalism (CI) and militant internationalism (MI) are mediated by political ideology, while none of the moral values have significant mediation effects on isolationism, reinforcing that isolationism is qualitatively different from the other foreign policy orientations. Analyses conducted using the mediation package (Tingley et al. 2012).

ideology—indeed, they are called foundations for that very reason. As such, estimating their effects on foreign policy attitudes while controlling for ideology is likely a form of posttreatment bias (King and Zeng 2007) that erroneously suppresses their true effect sizes. Thus, we perform a series of nonparametric mediation analyses (Imai et al. 2011), in which each of the five moral foundations' effects on CI, MI, and isolationism are mediated by political ideology, the results of which are depicted in Figure $2 .{ }^{3}$ Figure 2

${ }^{3}$ For each dependent variable, we estimate five mediation models, in which the impact of moral foundation $X_{i}$ on $Y$ is mediated by political ideology, controlling for the other $X$ s as pretreatment covariates along with the demographic characteristics from the previous analyses. Since the direct effect of $X$ on $Y$ represents all mechanisms through which $X$ affects $Y$ apart from mediator $M$, this strategy allows us to achieve an unbiased estimate of each mediation effect while controlling for possible confounding. We are grateful to Luke Keele for helpful discussions on this point. To facilitate a more straightforward set of mediation analyses with a continuous mediator, we drop the libertarians from the sample; see online Appendix $\S 8$ for mediation analyses that include libertarianism. plots three quantities of interest for each of the moral foundations: the average causal mediation effect (ACME,) which refers to the moral foundation's effect on foreign policy attitudes channeled through political ideology; the direct effect, which refers to the moral foundation's effect on foreign policy attitudes channeled through all mechanisms apart from political ideology; and the total effect, which represents the sum of the ACME and direct effects.

The left panel of Figure 2 presents the mediation effects of the moral foundations on CI. The two individualizing foundations have significant positive direct and indirect effects on CI: fairness and harm's effects on support for dovish foreign policies are partially transmitted by political ideology, but not exclusively so; $34.2 \%$ of fairness' effect on CI and $59.6 \%$ of harm's effect come through other mechanisms. In contrast, the binding foundations' negative effects on CI are largely mediated through ideology: they all have significant mediation effects on CI, but only ingroup has a significant direct effect. The middle 
panel shows that, as was the case with $\mathrm{CI}$, all of the moral foundations' effects on MI are mediated by political ideology; sensitivity analyses presented in online Appendix $\S 7$ show that both these sets of mediation effects are highly robust. However, we see a different pattern of results when we look at the direct effects: whereas the previous set of models showed that a greater proportion of the individualizing foundations' effects on CI tended to go through paths other than ideology (on average: $46.9 \%$ for the individualizing foundations versus $23.9 \%$ for the binding foundations), here we see that a greater proportion of the binding foundations' effects on MI went through other paths (on average: $4.7 \%$ for the individualizing foundations versus $50.7 \%$ for the binding ones).

Thus, not only do people with preferences for cooperation or the use of military force rely on opposing moral foundations (the former being high in the individualizing foundations and low in the binding ones and the latter being high in the binding foundations and low in the individualizing ones), but mediation analyses show opposing causal mechanisms at work: for CI, it is the individualizing foundations that are more likely to exert effects independent of ideology, while for MI, it is the binding foundations that are more likely to exert effects independent of ideology. This is in keeping with our theoretical predictions that the links between the binding foundations and MI and the individualizing foundations and CI would be the most direct. Finally, the right panel reconfirms that isolationism is largely disconnected from Haidt's five moral foundations: none of the moral foundations display significant mediation effects, and only one (ingroup) displays a significant direct effect.

\section{Moral Foundations and Specific Foreign Policy Issues}

Thus far, we have shown that general foreign policy orientations rely on different configurations of moral values, but we also investigate whether moral foundations predict attitudes toward specific policy issues. Figure 1(d-g) presents coefficient plots for a series of regression models estimating the relationship between the moral foundations and four specific policy attitudes: support for the Iraq war, support for a potential strike against the Iranian nuclear program, support for signing a successor to the Kyoto protocol to fight global warming, and support for the NATO intervention in Libya. ${ }^{4}$ These four issues were selected

\footnotetext{
${ }^{4}$ See online Appendix $\S 5$ for the regression table, omitted here to save space.
}

because they represent different combinations of idealistic and strategic ends: protecting the environment is a classic idealistic and cosmopolitan issue, while the war in Iraq and a strike against Iran solidly implicate the national interest in a strategic, material way. The multilateral intervention in Libya, however, was carried out for both strategic and humanitarian purposes. The results suggest two things. First, they reconfirm that foreign policy attitudes have moral foundations: highly significant relationships exist between the moral foundations and the specific policy attitudes, which as before remain robust to the inclusion of survey weights and demographic controls. Second, and more interestingly, we see distinct configurations of moral foundations across policy questions. Both the Iraq War and the Iran strike display a similar pattern similar to MI: supporters of these conflicts are high in the binding foundations and low in the individualizing ones. Moreover, support for a new Kyoto Protocol has very similar moral foundations to that of CI: backers of a new climate-change agreement are very high in both individualizing foundations and lower in the binding ones. Importantly, though, support for the humanitarian intervention in Libya displays a composite configuration of both individualizing and binding foundations. In that sense, we can see why humanitarian interventions - which often involve both strategic and ideological rationales-are likely to be used as wedge issues (Snyder, Shapiro, and Bloch-Elkon 2009): bipartisan segments of the public intuitively positively evaluate these missions, albeit for different reasons, creating cross-cleavages of support.

\section{Conclusion}

We thus find empirical evidence to support the realists' claim that the U.S. public is moralistic but not that morals are solely the domain of a liberal idealist or a necessarily erratic public. Drawing on Moral Foundations Theory, we find that moral intuitions are systematically associated with (and explain $50 \%$ of the variance in) preferences for MI and $\mathrm{CI}$-and that different sets of moral foundations underlie each orientation, except for isolationism, which is divorced from the classic five moral considerations.

These findings have important implications for a number of debates in IR. Haidt and Graham's (2007) criticism of previous research on moral psychology was that there was little consensus about what counts as moral; they thus sought to provide a comprehensive 
framework to answer this question through Moral Foundations Theory. In contrast, American IR theorists have displayed too much consensus about what constitutes morality in international politics, associating morality exclusively with liberal idealist arguments that, according to realists, run the risk of privileging moralistic concerns at the expense of more important national security matters. By demonstrating the positive impact of the binding foundations on MI, we show that morals are not solely the domain of Enlightenment ideals. What appears to liberal idealists as immoral or amoral-such as the aggressive pursuit of national security-emerges from morality as well, just of a different sort. This also applies to specific uses of force, such as the war in Iraq or airstrikes in Libya. Indeed, the fact that humanitarian interventions implicate both binding and individualizing foundations is one explanation for their capacity to build a diverse coalition of support. We also address concerns that emotional publics have inconsistent responses to foreign policy events, showing that despite the intuitionist origins of moral judgment, moral foundations lead to predictable patterns of foreign policy preferences.

Since our survey does not force respondents into evaluating trade-offs between moral values and material interests, we cannot speak to the depth of their normative obligations, a crucial test in showing that actors are bound by a "logic of appropriateness" (Herrmann and Shannon 2001). Future work should explore this question, along with how value anchors shape cognition in constructing policy preferences (Herrmann, Tetlock, and Visser 1999). In this sense, however, our results reject the conventional dichotomy between the logic of consequences and logic of appropriateness, in which choices are only explained by values if they cannot be explained by interests: similar to Johnston's (1995) argument that Chinese adherence to realpolitik principles stem from a "parabellum paradigm" in Chinese strategic culture, we show that the types of hawkish policies traditionally understood to be hard-headed expressions of power politics are in fact strongly predicted by the binding moral foundations-rather than values-based explanations being opposites, we find that values constitute perceptions of interests. Senator John McCain, like many other American policy makers, routinely gives speeches proclaiming that "for America, our interests are our values and our values are our interests" (2013). Our results lend empirical credence to these rhetorical flourishes.

Additionally, patterns of moral foundations contribute to our understanding of why foreign policy issues are often so polarizing: members of the public rely on different, fundamental intuitions about what types of policies are normatively preferable (cf. Graham, Haidt, and Nosek 2009). Since recent research has found that elites use moral rhetoric to mobilize the public, and that reframing policies in terms of specific moral foundations can alter constituencies of support, moral frames may be one technique decision makers can employ to mobilize support for their desired foreign policy options (Clifford and Jerit 2013). Although additional research should explore this question in further detail, policy makers may be able to build different coalitions of support for military interventions, for example, based upon whether they advocate for the intervention based on avoiding harm or protecting the ingroup-an interesting possibility given the classical realist claim that governments simply use moral rhetoric to further their own interests. Moralizing issues also makes them much more difficult to resolve (Ryan 2014; Skitka, Bauman, and Sargis, 2005). The same is no less likely to apply to foreign policy; to the extent that conflicts over strategic interests have a highly moral overlay, and that moralized issues are consistently found to be less conducive to compromise, many interstate disputes might be even more difficult to solve than we thought. By revealing that nonidealist foreign policies have moral foundations too, these results enrich the understanding of morality in IR and open up the door for future research.

\section{Acknowledgements}

We are grateful to audiences at Ohio State, ISA, and the USC Values, Ideology and Morality Lab, YourMorals.org for hosting the survey, and especially Scott Clifford, Chris Gelpi, Jesse Graham, Peter Hays Gries, Josh Gubler, Luke Keele, Kathleen McGraw, and Tim Ryan for helpful comments.

\section{References}

Ansolabehere, Stephen, Jonathan Rodden, and James M. Snyder. 2008. "The Strength of Issues: Using Multiple Measures to Gauge Preference Stability, Ideological Constraint, and Issue Voting." American Political Science Review 102 (2): 215-32.

Brewer, Marilynn B. 1999. "The Psychology of Prejudice: Ingroup Love or Outgroup Hate?” Journal of Social Issues 55 (3): 429-44.

Buckels, Erin E., and Paul D. Trapnell. 2013. "Disgust Facilitates Outgroup Dehumanization." Group Processes \& Intergroup Relations. Forthcoming. 
Carr, Edward Hallett. 1939. The Twenty Years' Crisis: 1919-1939. London: Macmillan.

Chang, LinChiat, and Jon A. Krosnick. 2009. "National Surveys Via RDD Telephone Interviewing Versus the Internet: Comparing Sample Representativeness and Response Quality." Public Opinion Quarterly 73 (4): 641-78.

Checkel, Jeffrey T. 1998. "The Constructivist Turn in International Relations Theory.” World Politics 50 (2): 324-48.

Chittick, William O., and Keith R. Billingsley. 1989. "The Structure of Elite Foreign Policy Beliefs." Western Political Quarterly 42 (2): 201-24.

Chittick, William O., Keith R. Billingsley, and Rick Travis. 1995. "A Three-Dimensional Model of American Foreign Policy Beliefs." International Studies Quarterly 39 (3): 313-31.

Christensen, Thomas J. 1996. Useful Adversaries: Grand Strategy, Domestic Mobilization, and Sino-American Conflict, 1947-1958. Princeton, NJ: Princeton University Press.

Clifford, Scott, and Jennifer Jerit. 2013. "How Words Do the Work of Politics: Moral Foundations Theory and the Debate over Stem Cell Research." Journal of Politics 75 (3): 659-71.

Converse, Philip E. 1964. The Nature and Origin of Belief Systems in Mass Publics. In Ideology and Discontent, ed. David E. Apter. New York: Free Press, 206-61.

Desch, Michael. 2003. "It is Kind to Be Cruel: The Humanity of American Realism." Review of International Studies 29 (3): 415-426.

Donnelly, Grant, Ravi Iyer, and Ryan T. Howell. 2012. “The Big Five Personality Traits, Material Values, and Financial Well-Being of Self-Described Money Managers." Journal of Economic Psychology 33 (6): 1129-42.

Doyle, Michael W. 1986. "Liberalism and World Politics." American Political Science Review 80 (4): 1151-69.

Drezner, Daniel W. 2008. "The Realist Tradition in American Public Opinion.” Perspectives on Politics 6 (1): 51-70.

Federico, Christopher M., Christopher R. Weber, Damla Ergun, and Corrie Hunt. 2013. "Mapping the Connections between Politics and Morality: The Multiple Sociopolitical Orientations Involved in Moral Intuition." Political Psychology 34 (4): 589-610.

Gelpi, Christopher, Peter D. Feaver, and Jason Reifler. 2009. Paying the Human Costs of War. Princeton, NJ: Princeton University Press.

Glenn, Andrea L., Ravi Iyer, Jesse Graham, Spassena Koleva and Jonathan Haidt. 2010. "Moral identity in psychopathy." Evolutionary Psychology 8 (3): 325-31.

Graham, Jesse, Jonathan Haidt, and Brian A. Nosek. 2009. "Liberals and Conservatives Rely on Different Sets of Moral Foundations." Journal of Personality and Social Psychology 96 (5): 1029-46.

Graham, Jesse, Jonathan Haidt, Spassena Koleva, Matt Motyl, Ravi Iyer, Sean P. Wojcik, and Peter H. Ditto. 2013. "Moral Foundations Theory: The Pragmatic Validity of Moral Pluralism." Advances in Experimental Social Psychology 47: 55-130.

Graham, Jesse, Brian A. Nosek, Jonathan Haidt, Ravi Iyer, Spassena Koleva, and Peter H. Ditto. 2011. "Mapping the moral domain." Journal of Personality and Social Psychology 101(2): 366-385.

Gries, Peter Hays. 2014. The Politics of American Foreign Policy: How Ideology Divides Liberals and Conservatives over Foreign Affairs. Stanford, CA: Stanford University Press.

Haidt, Jonathan. 2007. "The New Synthesis in Moral Psychology." Science 316(5827): 998-1002.
Haidt, J., J. Graham, and C. Joseph. 2009. "Above and Below Left-right: Ideological Narratives and Moral Foundations." Psychological Inquiry 20: 110-19.

Haidt, Jonathan. 2001. "The Emotional Dog and Its Rational Tail: A Social Intuitionist Approach to Moral Judgment." Psychological Review 108 (4): 814-34.

Haidt, Jonathan, and Jesse Graham. 2007. "When Morality Opposes Justice: Conservatives Have Moral Intuitions that Liberals May Not Recognize." Social Justice Research 20 (1): 98-116.

Hainmueller, Jens. 2012. "Entropy Balancing for Causal Effects: A Multivariate Reweighting Method to Produce Balanced Samples in Observational Studies." Political Analysis 20 (1): 25-46.

Herrmann, Richard K., Philip E. Tetlock, and Penny S. Visser. 1999. "Mass Public Decisions to Go to War: A CognitiveInteractionist Framework." American Political Science Review 93 (3): 553-73.

Herrmann, Richard K., and Vaughn P. Shannon. 2001. "Defending International Norms: The Role of Obligation, Material Interest, and Perception in Decision Making." International Organization 55 (3): 621-54.

Herz, John H. 1950. "Idealist Internationalism and the Security Dilemma." World Politics 2 (2): 157-80.

Hillygus, Sunshine, and Todd Shields. 2005. "Moral Issues and Voter Decision Making in the 2004 Presidential Election." PS: Political Science \& Politics 38 (2): 201-10.

Holsti, Ole R. 1992. "Public Opinion and Foreign Policy: Challenges to the Almond-Lippmann Consensus." International Studies Quarterly 36 (4): 439-66.

Holsti, Ole R., and James N. Rosenau. 1990. "The Structure of Foreign Policy Attitudes." Journal of Politics 52 (1): 94-125.

Holsti, Ole R., and James N. Rosenau. 1996. "Liberals, Populists, Libertarians, and Conservatives: The Link between Domestic and International affairs." International Political Science Review 17 (1): 29-54.

Howard, Rhoda E., and Jack Donnelly. 1986. "Human Dignity, Human Rights, and Political Regimes." American Political Science Review 80 (3): 801-17.

Hurwitz, Jon, and Mark Peffley. 1987. "How Are Foreign Policy Attitudes Structured?" American Political Science Review 81 (4): 1099-1120.

Imai, Kosuke, Luke Keele, Dustin H. Tingley, and Teppei Yamamoto. 2011. "Unpacking the Black Box of Causality: Learning about Causal Mechanisms from Experimental and Observational Studies." American Political Science Review 105 (4): 765-89.

Inglehart, Ronald. 1997. Modernization and Postmodernization: Cultural, Economic, and Political Change in 43 Societies. Princeton, NJ: Princeton University Press.

Iyer, Ravi, Spassena Koleva, Jesse Graham, Peter Ditto, and Jonathan Haidt. 2012. "Understanding Libertarian Morality: The Psychological Dispositions of Self-Identified Libertarians." PLoS ONE 7 (8): e42366.

Jervis, Robert. 1976. Perception and Misperception in International Politics. Princeton, NJ: Princeton University Press.

Jervis, Robert. 1994. "Hans Morgenthau, Realism, and the Scientific Study of International Politics." Social Research 61 (4): 853-76.

Johnston, Alastair Iain. 1995. Cultural Realism: Strategic Culture and Grand Strategy in Chinese History. Princeton, NJ: Princeton University Press. 
Kant, Immanuel. 1970. Perpetual Peace: A Philosophical Sketch. Cambridge: Cambridge University Press.

Kennan, George F. 1951. American Diplomacy, 1900-1950. Chicago: University of Chicago Press.

Kertzer, Joshua D. 2013. "Making Sense of Isolationism: Foreign Policy Mood as a Multilevel Phenomenon." Journal of Politics 75 (1): 225-40.

Kertzer, Joshua D., and Kathleen M. McGraw. 2012. "Folk Realism: Testing the Microfoundations of Realism in Ordinary Citizens." International Studies Quarterly 56 (2): 245-58.

King, Gary, and Langche Zeng. 2007. "When Can History Be Our Guide? The Pitfalls of Counterfactual Inference.” International Studies Quarterly 51 (1): 183-210.

Liberman, Peter. 2006. "An Eye for an Eye: Public Support for War Against Evildoers.” International Organization 60 (3): 687-722.

Lippmann, Walter. 1955. Essays in the Public Philosophy. Boston: Little, Brown.

Lipset, Seymour Martin. 1988. "American exceptionalism reaffirmed.” International Review of Sociology 2 (3): 25-69.

Lumsdaine, David Halloran. 1993. Moral Vision in International Politics: The Foreign Aid Regime, 1949-1989. Princeton, NJ: Princeton University Press.

McCain, John. "Remarks by Senator John McCain at the Center for a New American Security: A New Republican Internationalism." Speech, Washington, DC, April 18, 2013. John McCain. http://mccain.senate.gov/public/index.cfm/speeches.

Mead, Walter Russell. 2002. Special Providence: American Foreign Policy and How It Changed the World. New York: Routledge.

Mearsheimer, John J. 2001. The Tragedy of Great Power Politics. New York: W.W. Norton.

Mondak, Jeffrey J. 2010. Personality and the Foundations of Political Behavior. Cambridge: Cambridge University Press.

Morgenthau, Hans J. 1951. In Defense of the National Interest. New York: Alfred A. Knopf.

Morgenthau, Hans J. 1985. Politics Among Nations: The Struggle for Power and Peace. 6th ed. Boston: Alfred A. Knopf.

Murray, A. J. H. 1996. "The Moral Politics of Hans Morgenthau." Review of Politics 58 (1): 81-107.

Murray, Shoon, and Jonathan Cowden. 1999. "The Role of "Enemy Images" and Ideology of Elite Belief Systems." International Studies Quarterly 43 (3): 455-81.

Murray, Shoon Kathleen. 1996b. Anchors Against Change: American Opinion Leaders' Beliefs After the Cold War. Ann Arbor: University of Michigan Press.

Nicholson, Michael. 1998. "Realism and Utopianism Revisited." Review of International Studies 24 (5): 65-82.

Nincic, Miroslav. 1997. "Domestic Costs, the U.S. Public, and the Isolationist Calculus." International Studies Quarterly 41 (4): 593-610.

Nincic, Miroslav, and Jennifer Ramos. 2011. "Torture in the Public Mind." International Studies Perspectives 12 (3): 231-249.

Osgood, Robert Endicott. 1953. Ideals and Self-Interest in America's Foreign Relations: The Great Transformation of the Twentieth Century. Chicago: University of Chicago Press.
Owen, John M. 1994. "How Liberalism Produces Democratic Peace." International Security 19 (2): 87-125.

Price, Richard. 2008. "Moral Limit and Possibility in World Politics." International Organization 62 (2): 191-220.

Rathbun, Brian C. 2007. "Hierarchy and Community at Home and Abroad: Evidence of a Common Structure of Domestic and Foreign Policy Beliefs in American Elites." Journal of Conflict Resolution 51 (3): 379-407.

Rokeach, Milton. 1973. The Nature of Human Values. New York: Free Press.

Ryan, Timothy J. 2014. "Reconsidering Moral Issues in Politics." Journal of Politics 76(2): 380-397.

Schwartz, Shalom H. 1994. "Are There Universal Aspects in the Structure and Contents of Human Values?" Journal of Social Issues 50 (4): 19-45.

Skitka, Linda J., Christopher W. Bauman, and Edward G. Sargis. 2005. "Moral Conviction: Another Contributor to Attitude Strength or Something More?" Journal of Personality and Social Psychology 88 (6): 895-917.

Smith, C., and S. Vaisey. 2010. "Charitable Giving and Moral Foundations in a Nationally Representative Sample." Unpublished manuscript.

Snyder, Jack, Robert Y. Shapiro, and Yaeli Bloch-Elkon. 2009. "Free Hand Abroad, Divide and Rule at Home." World Politics 61 (1): 155-87.

Tannenwald, Nina. 1999. "The Nuclear Taboo: The United States and the Normative Basis of Nuclear Non-Use." International Organization 53 (3):433-68.

Tingley, Dustin, Teppei Yamamoto, Luke Keele, and Kosuke Imai. 2012. "mediation 4.0: Statistical Analysis of Causal Mechanisms Using R." Journal of Statistical Software. Forthcoming.

Turiel, Elliot. 1983. The Development of Social Knowledge: Morality and Convention. Cambridge: Cambridge University Press.

Wilson, Peter. 1998. "The Myth of the 'First Great Debate'." Review of International Studies 24 (5): 1-16.

Wittkopf, Eugene R. 1990. Faces of Internationalism: Public Opinion and American Foreign Policy. Durham, NC; Duke University Press.

Joshua D. Kertzer is an Assistant Professor of Government at Harvard University, Cambridge, MA 02138 .

Kathleen E. Powers is a Ph.D. Candidate in the Department of Political Science at the Ohio State University, Columbus, $\mathrm{OH} 43210$.

Brian C. Rathbun is an Associate Professor in the School of International Relations at the University of Southern California, Los Angeles, CA 90089.

Ravi Iyer is the Chief Data Scientist for Ranker, Los Angeles CA 90048. 